\title{
Crowdfunding regulation models: international and Russian experience in context of sustainable development
}

\author{
Elena Prokofeva ${ }^{1}$, Marina Chudinovskikh ${ }^{2 *}$, Yulia Kuvaeva ${ }^{2}$, Olesya Kononenko ${ }^{2}$, \\ and Nadezhda Boronenkova ${ }^{2}$ \\ ${ }^{1}$ Academy of the Ministry of Internal Affairs of the Republic of Belarus, Masherova 6, 220005 \\ Minsk, Belarus \\ ${ }^{2}$ Ural State University of Economics, 8 Marta st,, 62, 620144Ekaterinburg, Russia
}

\begin{abstract}
The conditions, promoting active development of crowdfunding market through which the so-called "alternative financing" is implemented, have been created in the global economy in the last few years. The article discusses the transformation experience of crowdfunding model types during the period from 2014, describes the existing regimes of legal regulation of crowdfunding in worldwide practice. Special attention is given to the description of Russian legal initiative aimed at the implementation of crowd-technologies in the investment activities. The authors identified three approaches to the crowdfunding regulation: prohibited, self-regulated and regulated. The Russian approach was changed from self-regulated to regulated with the entry into force of new laws from January 1, 2020. In Republic of Belarus crowdfunding is still self-regulated. Crowdfunding is considered by the authors as a promising financial technology that contributes to sustainable development and economic growth.
\end{abstract}

\section{Introduction}

The 2015 UN Summit on Sustainable Development resulted in the formulation of 17 sustainable development goals, among which economists pay particular attention to two areas: "promoting sustained, inclusive and sustainable economic growth, full and productive employment and decent work for all" and "building solid infrastructure, promoting inclusive and sustainable industrialization and innovation". These goals are a kind of call into action, which can be realized by modern tools of the digital economy. As a result of the IT introduction, the possibility of direct communication between participants in economic processes significantly increases, which led to the creation of a crowd economy a system of economic processes formed by a mass of ordinary players, identical in a set of rights and opportunities of players in economic relations. The creating process of new hightech economy sectors and effective innovative renewal of traditional sectors is essential to the transformational transition of the Russian economy to a new technological order, which

* Corresponding author: chud-marina@mail.ru 
in turn, is not possible without the use of modern approaches, including alternative financing.

We study the essence of the crowdfunding phenomenon from both economic and legal points of view. An analysis of the various regions experience of the world is necessary for the purposes of its testing and adaptation in the conditions of the economy of Russian Federation and Republic of Belarus. Comparative analysis of the crowdfunding regulation can help to reveal gaps in regulatory framework.

\section{Methods}

Vigorously crowdfunding development entails an increase in the number of scientific papers and studies. Crowdfunding projects are very heterogeneous. Crowdfunding platforms can be used for both the financing small - scale projects and the extensive research and development [8].

This study objective is to systematize the crowdfunding models existing in European countries and Russia, as well as to identify legal approaches to the crowdfunding regulation. The research included the following phases:

- statistical analysis;

- assessment of the developed approaches to the crowdfunding models classification;

- crowdfunding regulatory framework study.

The entry into force on 2020 of the Federal Law "On the investment promotion using investment platforms and on changes to the individual relevant pieces of legislation of the Russian Federation" dated 2 August 2019 N 259 - FL is important for the Russian Federation. The conducted study has allowed the authors to highlight crowdfunding regulation models and provided the outlook on the effectiveness of regulatory principles for the Russian Federation.

\section{Results}

The research department of International Organization of Securities Commissions (IOSCO) started studying the economic nature of the crowdfunding market legal regulation in in 2014 [3]. According to IOSCO crowdfunding (from the English word "crowd", "crowdfunding" - financing of the crowd) is a general term describing the using of small money amounts received from a large number of private persons or organizations to finance a project, business or personal loan and other needs through the Internet platform. Crowdfunding, in the IOSCO definition proposed in 2014, had four subcategories:

- $\quad$ peer - to - peer (debt) lending;

- donation crowdfunding;

- reward crowdfunding;

- joint - stock (share) crowdfunding.

The rapid development of the alternative financing market based on crowdfunding technology and its massive use first in European countries and later around the world prejudged the transformation of model types of crowdfunding. In this regard, the Cambridge Center for Alternative Finance at the University of Cambridge has been regularly publishing reports on the state of the alternative finance industry in the European region since 2015, and in 2020 for the first time published a global report that collected data from different regions of the world. As of 2020, the global alternative financing market is relatively diverse and in the modern world it is represented not by four, as in 2014, but by 
fifteen distinctive model types operating in different regions [9]. Table 1 describes the model types of crowdfunding identified by the Cambridge Center for Alternative Finance.

Table 1. Global taxonomy of model crowdfunding types

\begin{tabular}{|c|c|c|}
\hline Model & Description & $\begin{array}{l}\text { Funding } \\
\text { (2019), billion } \\
\text { USD } \\
\end{array}$ \\
\hline $\begin{array}{c}\text { Peer }- \text { to }- \text { Peer } \\
\text { Consumer Lending } \\
\end{array}$ & Investors provide debt financing to individual consumers & 195.00 \\
\hline $\begin{array}{l}\text { Peer - to - Peer Business } \\
\text { Lending }\end{array}$ & Investors provide debt financing to a business borrower & 50.00 \\
\hline $\begin{array}{l}\text { Balance Sheet Business } \\
\text { Lending }\end{array}$ & $\begin{array}{l}\text { The platform provides debt financing directly to a business } \\
\text { borrower. The platform assumes the risk itself }\end{array}$ & 21.00 \\
\hline $\begin{array}{l}\text { Balance Sheet Property } \\
\text { Lending } \\
\end{array}$ & $\begin{array}{l}\text { The platform provides credit secured by property directly to } \\
\text { the consumer or business borrower }\end{array}$ & 11.00 \\
\hline $\begin{array}{c}\text { Balance Sheet } \\
\text { Consumer Lending }\end{array}$ & $\begin{array}{l}\text { The platform provides debt financing directly to an } \\
\text { individual borrower. The platform assumes the risk itself }\end{array}$ & 10.00 \\
\hline $\begin{array}{l}\text { Peer - to - Peer Property } \\
\text { Lending }\end{array}$ & $\begin{array}{l}\text { Investors provide the debt financing against consumer or } \\
\text { business borrower property }\end{array}$ & 6.00 \\
\hline Invoice Trading & $\begin{array}{l}\text { Platforms allow businesses to sell individual invoices in } \\
\text { order to free up cash, to an online community of investors. }\end{array}$ & 3.20 \\
\hline $\begin{array}{c}\text { Real Estate } \\
\text { Crowdfunding }\end{array}$ & $\begin{array}{l}\text { Investors provide financing for the acquisition of property } \\
\text { (real-estate) }\end{array}$ & 2.96 \\
\hline $\begin{array}{l}\text { Equity-based } \\
\text { Crowdfunding }\end{array}$ & $\begin{array}{l}\text { Investors fund startup companies and small businesses in } \\
\text { return for equity }\end{array}$ & 1.52 \\
\hline $\begin{array}{l}\text { Reward-based } \\
\text { Crowdfunding }\end{array}$ & $\begin{array}{l}\text { Sponsors provide financing to individuals, projects or } \\
\text { companies in exchange for non-cash rewards or products }\end{array}$ & 0.88 \\
\hline Debt-based Securities & $\begin{array}{l}\text { Private individuals or institutional investors buy equity } \\
\text { securities, bonds }\end{array}$ & 0.85 \\
\hline $\begin{array}{l}\text { Donation-based } \\
\text { Crowdfunding }\end{array}$ & $\begin{array}{l}\text { Donors provide financing to private individuals, projects or } \\
\text { companies on a charitable basis without expecting monetary } \\
\text { or material rewards }\end{array}$ & 0.64 \\
\hline Revenue Sharing & $\begin{array}{c}\text { Investors purchase securities from a company (stocks or } \\
\text { bonds) and receive a share in the profits or royalty }\end{array}$ & 0.40 \\
\hline Mini Bonds & $\begin{array}{l}\text { Investors finance a company and receive a fixed return over } \\
\text { a set period of time, with the initial investment returned at } \\
\text { the end of the prescribed duration. The regulatory } \\
\text { requirements are much less stringent for mini bonds than } \\
\text { for listed bonds. }\end{array}$ & 0.33 \\
\hline Community Shares & $\begin{array}{l}\text { Investors finance projects wjth a positive social impact for } \\
\text { the community it serves. }\end{array}$ & 0.10 \\
\hline Other & Other models that go beyond the existing taxonomy & 0.41 \\
\hline In total & & 304.29 \\
\hline
\end{tabular}

As shown in the above table, in the global economy, crowdfunding model types have evolved significantly in comparison with 2014, increased in their diversity and expanded the possibilities of conducting operations, including in the international market. In so doing, the significance of certain models decreases from year to year that allows other models move in the direction of growth and, as some experts say, such changes are explained:

- response to the economy development as a whole;

- quality regulation in this area;

- competition result [2].

An analysis of data from a Cambridge Center for Alternative Finance report, published in 2020, suggests that the largest amount of funds has recently been attracted and issued to consumers as a loan through the P2P Consumer Lending model (about $64 \%$ of the total volume of alternative financing). The P2P Business Lending model ranks second in the rating in terms of funding (16\%). Following are Balance Sheet Business Lending (7\%), Balance Sheet Property Lending (3.5\%), Balance Sheet Consumer Lending (3\%), P2P 
Property Lending (2\%) and Invoice Trading (1\%). The rest of the model types of crowdfunding hold less than 1 percent in the total volume of alternative financing through crowdfunding [9].

The leader among the countries implementing various model crowdfunding types on their territory as of 2019 was China (\$215.37 billion in debt financing, \$22.18 million in equity financing (shares) and \$ 5.79 in financing through non-investment models). The experience of China and the high growth rates of its economy confirm our hypothesis that crowdfunding contributes to sustainable development. The USA is in second place with the financing volume in the debt segment of $\$ 57.67$ billion, in the equity segment $-\$ 2.55$ billion, and in the non-investment segment - \$696.50 million. The third largest global region was the UK: $\$ 9.31$ billion - the debt segment, $\$ 870.19$ million - the equity segment and $\$ 76.60$ million - non-investment crowdfunding [9]. It should be noted that in all previous years of survey (2015-2017), the United Kingdom was the largest market for alternative online financing [5].

In the European region, using debt crowdfunding models, $\$ 6.60$ billion was raised, with equity - \$883.32 million, non-investment models made it possible to attract $\$ 237.75$ million. For the Asia-Pacific region (excluding China), the figures were as follows: debt model types of crowdfunding - $\$ 5.34$ billion, equity - \$504.84 million, non-investment crowdfunding - \$277.28 million.

According to the results of 2018, researchers at the Cambridge Center for Alternative Finance estimate the total amount of funds attracted through digital platforms in Russia at the level of $\$ 118$ million [9]. The Russian crowdfunding market showed negative dynamics in 2019. Its volume amounted to about 75 million US dollars. Among the reasons for the weak development of crowdfunding, we can note the lack of the necessary regulatory framework (up to 2020), weak trust from investors, and a low level of financial literacy. The Central Bank of Russia identifies only 4 crowdfunding models: P2B lending (investor - individual, borrower-legal entity), P2P lending (investor and borrowerindividuals), rewards-crowdfunding. B2B lending (investors and borrowers are legal entities). The largest in Russia is the P2B lending sector. Comparing the presented models with the data in table 1, we can conclude that in the Russian Federation, many models are not yet represented or are poorly represented. In addition, we found a significant discrepancy in the understanding of model types of crowdfunding. In Russia, classification is carried out by subject composition.

The importance of developing crowdfunding as a tool for sustainable development is noted in the "State program of innovative development of the Republic of Belarus for 20162020". Among the largest platforms are Uley.by and Talaka.org, which provides an opportunity for investors to receive non-financial rewards for participating in their financing of a social or cultural project. The amount of funds raised through crowdfunding platforms does not exceed $\$ 10$ mln per year.

Against the background of the alternative financing market significant developing, the regulation of this area remains a key challenge globally so far, though in world practice the features of three main approaches were clearly traced in the crowdfunding regulation:

1. The "Prohibited" approach, which should be understood as a prohibited mode of the crowdfunding platforms functioning.

2. The "Self Regulation" approach is an approach in which the country does not have common requirements for crowdfunding, but the platforms independently define the rules for their work. Within this approach, internal platforms rules for selecting and evaluating projects to ensure investor confidence are of great importance [4]. In Republic of Belarus crowdfunding is still self-regulated.

3. The "Regulated" approach is regulated regime. For many developed countries, the most common is the "Regulated" regime, in which the national legislator has developed the 
necessary regulatory framework. As a rule, the laws limit the amount of investment through crowdfunding platforms. This approach is used, for example, in Germany [6], in Great Britain [5]. Developing countries, even as large as India, do not yet have a sufficient regulatory framework, which hinders the development innovation activity [10]. Researchers in Turkey note a similar situation [1].

If in developed countries at least general approaches to the regulation of the alternative financing market have been formed today, in Russia and Republic of Belarus the situation with the regulatory impact on this market until 2020 was outside beyond the legal regulation. Accordingly, in the Russian Federation there were no technical and legal constructions of economic concepts used by the crowdfunding market in developed economies. The positive expectations in this direction are associated with the adoption of the Federal Law "On the investment promotion using investment platforms and on changes to the individual relevant pieces of legislation of the Russian Federation" dated 2 August 2019 N 259 - FL, which entered into force on January 1, 2020.

However, in comparison with the rich "assortment" of alternative financial models that have formed in different regions of the world by 2020 (Table 1), the Russian legislator, in terms of regulatory impact, describes only three models:

- granting loans;

- purchase of issued securities placed using the investment platform, except of credit institutions securities, non-bank financial institutions, as well as structured bonds and securities intended for qualified investors;

- purchase of non-issued securities - utilitarian digital rights (the right to demand the transfer of a thing (things), the right to demand the transfer of exclusive rights to the results of intellectual activity or the right to use the results of intellectual activity, the right to demand the performance of work or the services provision) [7].

\section{Conclusions}

According to the results of the study, we concluded that the Russian and Belarus practice of using crowdfunding and its regulation is well below the global one. The Federal Law "On the investment promotion using investment platforms" has come into force in Russian federation since 01.01.2020 that allow predict ordering of the market by changing the regulatory approach from self-regulated to regulated. Experts of the Analytical Center under the Government of the Russian Federation, the Ministry of Economic Development of the Russian Federation, the Ministry of Foreign Affairs of the Russian Federation, the Federal State Statistics Service and the UN Information Center in Moscow in a special Voluntary National Review "On the implementation of the 2030 Agenda for Sustainable Development" recognize the need to expand access of economic entities to various types of financial services, which should fully include crowdfunding.

In this regard the investors and businesses interest in alternative financing models, including model types of crowdfunding, will largely depend on the level of regulatory requirements. Bearing in mind the positive changes in domestic legislation, the use of crowdfunding digital platforms as a tool to implement alternative financing models is possible, but subject to the application and adaptation of the experience of developed countries in this direction. The further development of the crowdfunding legislative regulation requires continuing research of Russian and International experience. Crowdfunding is considered as a perspective financial technology that contributes to sustainable development and economic growth. 


\section{References}

1. P. Belleflamme, N. Omrani, M. Peitz, Inf. Econ. and Policy, 33 (2015)

2. D. Brüntje, O. Gajda, Crowdfunding in Europe - State of the Art in Theory and Practice: textbook (2016)

3. Crowd-funding: An Infant Industry Growing Fast Report (2014)

4. D. J. Cumming, S. A. Johan, Ye. Zhang, J. of Banking \& Finance, 108 (2019)

5. G. Gutfleisch, European Company Law J., 3 (2018)

6. B. J. Hartmann, J. of European Consumer and Market Law, 6 (2017)

7. Yu. Kuvaeva, M. Chudinovskikh, Financial econ., 12 (2019)

8. E. Mollick, J. of Bus.Venturing, 29 (1) (2014)

9. The Global Alternative Finance Market Benchmarking Report, Trends, Opportunities and Challenges for Lending, Equity, and Non-Investment Alternative Finance Models (2020)

10. A. Tripathy, Bus. Law Rev., 5 (2018) 